\title{
ANALISIS REAKSI PASAR MODAL INDONESIA TERHADAP PENETAPAN UNDANG UNDANG CIPTA KERJA TAHUN 2020
}

\author{
Francisca Kristiastuti ${ }^{1}$, Utari Kartika Sari ${ }^{2}$ \\ ${ }^{1}$ Fakultas Ekonomi, Universitas Nurtanio, Bandung \\ ${ }^{2}$ Fakultas Ekonomi, Universitas Nurtanio, Bandung \\ ${ }^{1}$ francisca.lulu75@gmail.com \\ ${ }^{2}$ utarikartika19@gmail.com
}

\begin{abstract}
ABSTRAK
Undang Undang Cipta Kerja Tahun 2020 yang disahkan pada tanggal 5 Oktober 2020 dinilai memberikan dampak yang positif bagi pasar modal Indonesia. Kandungan informasi dalam penetapan Undang-Undang Cipta Kerja dimanfaatkan oleh investor dalam membuat keputusan investasi. Penelitian ini bertujuan untuk menganalisis reaksi pasar modal Indonesia yang dilakukan dengan cara mengamati pergerakan harga saham dan volume perdagangan saham. Pergerakan harga saham digunakan untuk melihat ada tidaknya abnormal return, sedangkan volume perdagangan digunakan untuk melihat ada tidaknya peningkatan trading volume activity. Penelitian ini menggunakan metode studi peristiwa dengan periode pengamatan selama 21 hari yang terdiri dari 10 hari sebelum dan 10 hari setelah pengumuman penetapan Undang Undang Cipta Kerja tahun 2020. Sampel penelitian adalah 14 perusahaan manufaktur yang sahamnya terdaftar dalam Indeks LQ 45 dengan kriteria tertentu. Hasil penelitian menunjukan bahwa tidak terjadi perbedaan pada rata-rata abnormal return antara sebelum dan sesudah pengumuman penetapan Undang Undang Cipta Kerja tahun 2020. Akan tetapi terdapat perbedaan pada rata-rata trading volume activity saat sebelum dan sesudah pengumuman penetapan Undang Undang Cipta Kerja tahun 2020.
\end{abstract}

Kata kunci: Abnormal Return, Trading Volume Activity, Undang Undang Cipta Kerja

\begin{abstract}
The 2020 Job Creation Law of Indonesia (Ciptaker), which was passed on October 5, 2020, is considered to have a positive impact on the Indonesian capital market. The insights in the stipulation of the Job Creation Act are well utilized by investors in making investment decisions. This research aims to analyze the reaction of the Indonesian capital market by observing the movement of stock prices and stock trading volume. The movement of stock prices is used to examine whether there is an abnormal return, while the trading volume is used to see whether there is an increase in trading volume activity. This research uses an event study method with an observation period of 21 days consisting of 10 days before and 10 days after the announcement of the 2020 Job Creation Act stipulation. The sample consists of 14 manufacturing companies whose shares are listed in the $L Q 45$ Index with certain criteria. The results show that there was no difference in the average abnormal return between before and after the announcement of the 2020 Job Creation Act stipulation. However, there was a difference in the average trading volume activity before and after the $2020 \mathrm{Job}$ Creation Act announcement.
\end{abstract}

Keywords: Abnormal Return, Trading Volume Activity, Undang Undang Cipta Kerja

\section{PENDAHULUAN}

Investasi adalah salah satu sumber pembiayaan bagi pembangunan khususnya di bidang ekonomi. Definisi sederhana dari investasi adalah pembelian modal atau barang yang tidak dikonsumsi, namun akan digunakan untuk kegiatan produktif sehingga menghasilkan barang atau jasa di masa depan dan memberi keuntungan. Istilah investasi berkaitan dengan berbagai aktivitas. Investasi dilakukan dengan menanamkan sejumlah dana pada aset riil maupun aset finansial. Investasi pada asset riil seperti tanah, emas, mesin produksi atapun bangunan, sedangkan aset finansial seperti deposito, saham, reksadana, sukuk maupun obligasi (Tandelilin, 2017).

Guna menarik dana investasi masuk ke Indonesia, dilakukan berbagai upaya seperti menarik investasi dari dalam negeri maupun investasi dari luar negeri. Salah satu langkah yang dilakukan guna mendorong peningkatan investasi ini adalah dengan penyederhanaan peraturanperaturan yang berlaku di Indonesia. Harus diakui bahwa masih banyak peraturan yang berlaku di Indonesia ini bersifat tumpang tindih, untuk itu Presiden Joko Widodo memunculkan istilah "Omnibus Law" pada saat pelantikan Presiden periode kedua, Oktober 2019. Omnibus berasal dari Bahasa Latin yang artinya untuk semuanya, dalam 
konteks hukum omnibus law dapat diartikan sebagai hukum yang mencakup semua atau satu undang-undang yang mengatur banyak hal. Dalam kaitan hukum di Indonesia, Omnibus Law ini dapat diartikan sebagai satu undang-undang yang akan sekaligus merevisi beberapa atau bahkan puluhan undang-undang yang telah ada dan berlaku.

Omnibus law yang pertama dibahas adalah Omnibus Law Undang Undang Cipta Kerja (UU Cipta Kerja). UU Cipta Kerja seharusnya dapat menyelesaikan permasalahan ketenagakerjaan Indonesia. Informasi dalam undang-undang ini juga dimaksudkan untuk memberikan solusi atas penurunan nilai investasi di Indonesia saat ini. UU Cipta Kerja akan membuat proses perizinan menjadi lebih efisien dan mudah bagi investor domestik dan asing. Dengan kebijakan ini diharapkan lingkungan investasi di Indonesia menjadi lebih baik sehingga investor domestik maupun asing tertarik untuk berinvestasi di negara ini. Hal ini juga dapat meningkatkan peluang kerja baru di berbagai industri (Kementerian Investasi, 2020)

Penetapan UU Cipta Kerja ini dipercaya akan mampu meningkatkan perkembangan sektorsektor industri di Indonesia. Salah satu sektor yang dipercaya terdampak positif adalah sektor manufaktur. Munculnya UU Cipta Kerja diharapkan mampu mendorong produktivitas industri manufaktur, yang pada gilirannya akan membuat daya saing produk Indonesia menjadi lebih tinggi dan lebih kuat (CNN Indonesia, 2020).

Sementara itu, pertumbuhan manufaktur diperkirakan akan mampu mendorong investasi domestik. Berdasarkan data dari Badan Koordinasi Penanaman Modal (BKPM), daftar investasi untuk industri manufaktur mencapai Rp 1,048 triliun pada tahun 2019-2023 dan terbagi dalam beberapa sub sektor. Dengan adanya UU Cipta Kerja diharapkan dapat memfasilitasi pelaksanaan komitmen investasi yang sudah diajukan ke BKPM (Kementerian Investasi, 2020).

Munculnya Omnibus Law Cipta Kerja membawa dampak positif bagi pasar modal, yang terlihat dari kenaikan Indeks Harga Saham Gabungan (IHSG) yang melampaui $1 \%$ sehari setelah pemberlakuan undang-undang itu yaitu pada 5 Oktober 2020 dan hari-hari penutupan perdagangan berikutnya. Posisi penutupan IHSG menguat hingga 5\% pada perdagangan hingga 14 Oktober 2020 (Utami D. N., 2020). Pasar modal Indonesia merespon secara positif penetapan UU Cipta Kerja, hal ini bisa dianggap bahwa para pelaku pasar modal percaya Omnibus Law ini dapat memberikan dampak positif bagi investasi asing di Indonesia (Sugianto, 2020). Penguatan IHSG ini terjadi karena adanya pergerakan harga saham di lantai bursa. Hartono (2019) menyatakan bahwa harga saham di pasar bursa ditentukan oleh permintaan dan penawaran saham bersangkutan di pasar bursa pada saat tertentu. Harga saham akan menguat pada saat permintaan pelaku pasar terhadap suatu saham tertentu mengalami peningkatan dan akan melemah pada saat terjadi penurunan permintaan terhadap saham tersebut. Ada banyak faktor yang mempengaruhi harga saham ini misalnya adalah kinerja perusahaan, kinerja industri, faktor lingkungan ekonomi makro serta sentimen pasar terhadap kondisi tertentu. Salah satu faktor yang sangat penting adalah faktor lingkungan ekonomi makro yang berkaitan dengan regulasi pemerintah (Prihastini \& Suprasto, 2017), salah satunya adalah adanya undang-undang yang berkaitan dengan cipta kerja ini.

Perubahan harga saham yang terjadi setelah pengumuman penetapan UU Cipta Kerja ini menunjukkan bahwa para pelaku pasar bereaksi terhadap sebuah informasi. Studi yang membahas mengenai dampak dari pengumunan dan atau informasi terhadap harga saham sering disebut dengan event study (Tandelilin, 2017). Penelitian ini membahas mengenai dampak pengumuman penetapan UU Cipta Kerja terhadap Abnormal Return dan Trading Volume Activity pada saham di sektor manufaktur khususnya yang terdaftar dalam Index LQ45 yang dipercaya akan sangat terdampak oleh adanya penerapan UU Cipta Kerja ini. Para pelaku pasar dipercaya akan makin banyak berivestasi di saham-saham sektor manufaktur karena percaya bahwa sektor ini akan makin berkembang sebagai dampak positif perubahan peraturan perundang-undangan yang akan makin memberikan kemudahan sektor manufaktur berkembang dimasa depan. 


\section{KAJIAN TEORI}

\section{Undang-Undang Cipta Kerja Tahun 2020}

Undang-Undang Cipta Kerja No. 11

Tahun 2020 tentang Cipta Kerja diharapkan dapat menyerap tenaga kerja sebesar-besarnya dalam menghadapi persaingan yang semakin ketat dan tuntutan globalisasi ekonomi. Cipta kerja merupakan upaya penciptaan lapangan kerja melalui upaya pemajuan, perlindungan dan penguatan koperasi dan UMKM, peningkatan ekosistem investasi, penyederhanaan usaha, investasi pemerintah pusat dan percepatan proyek strategis nasional. Sepuluh ruang lingkup UU ini antara lain : 1) peningkatan ekosistem investasi dan kegiatan berusaha; 2) ketenagakerjaan; 3) kemudahan, perlindungan, serta pemberdayaan Koperasi dan UMK-M; 4) kemudahan berusaha; 5) dukungan riset dan inovasi; 6) pengadaan tanah; 7) kawasan ekonomi; 8) investasi Pemerintah Pusat dan percepatan proyek strategis nasional; 9) pelaksanaan administrasi pemerintahan; dan 10) pengenaan sanksi.

UU Cipta Kerja diyakini dapat mendorong reindustrialisasi Indonesia. Selain untuk mendorong pertumbuhan industri manufaktur, UU Cipta Kerja bertujuan untuk menciptakan lapangan kerja. Manufaktur dan tenaga kerja adalah dua hal yang saling terkait sehingga pertumbuhan manufaktur akan berdampak positif pada penciptaan lapangan kerja (Kementerian Perindustrian Republik Indonesia, 2020).

\section{Return Saham}

Menurut Tandelilin (2017), return merupakan hasil dari naik atau turunnya harga surat berharga dan dapat mengakibatkan keuntungan atau kerugian bagi investor. Return dapat berupa realisasi pendapatan yang dihasilkan atau pendapatan yang diharapkan di masa yang akan datang (Hartono, 2018).

\section{Abnormal Return}

Menurut Hartono (2018), pengembalian tidak normal (abnormal return) adalah selisih antara return aktual dan return yang diharapkan. Pengembalian tidak normal dihitung pada setiap tanggal periode jendela untuk setiap sekuritas. Pengembalian tidak normal untuk setiap sekuritas dihitung secara cross-sectional dan dirata-ratakan untuk memperoleh nilai rata-rata pengembalian tidak normal pada setiap tanggal. Studi peristiwa menganalisis pengembalian abnormal pada saham yang dapat terjadi sebagai akibat dari pengumuman informatif seperti pengumuman Undang-Undang Penciptaan Lapangan Kerja.

\section{Trading Volume Activity}

Selain harga, salah satu indikator yang menarik perhatian investor dalam perdagangan saham adalah aktivitas perdagangannya. Menurut Tandelilin (2017), indikator tingkat aktivitas perdagangan saham dapat dilihat dari volume lembar saham yang diperjualbelikan oleh investor serta besarnya nilai transaksi selama periode tertentu.

Aktivitas volume perdagangan (Trading Volume Activity) digunakan untuk mengetahui apakah kandungan informasi dalam sebuah peristiwa dapat dimanfaatkan oleh investor untuk membuat keputusan perdagangan. Aktivitas volume perdagangan diformulasikan sebagai berikut (Husnan, Hanafi, \& Wibowo, 1996) :

TVA $=\frac{\sum \text { Saham perusahaan } \mathrm{i} \text { yang diperdagangkan pada waktu } \mathrm{t}}{\Sigma \text { Saham perusahaan } \mathrm{i} \text { yang beredar pada waktu } \mathrm{t}}$

\section{Indeks LQ45}

Indeks LQ45 terdiri dari 45 saham di Bursa Efek Indonesia (BEI) yang sangat likuid dan memiliki kapitalisasi pasar yang besar, serta lolos seleksi berdasarkan beberapa kriteria seleksi. BEI memantau kinerja ke-45 saham yang tercatat dalam indeks LQ45 ini secara berkala. Adapun saham yang tergabung dalam indeks LQ45 dipertukarkan setiap enam bulan, yaitu pada bulan Februari dan Agustus (Tandelilin, 2017).

\section{Studi Peristiwa (Event Study)}

Hartono (2019) mengklaim bahwa riset peristiwa dilakukan untuk mengamati reaksi pasar terhadap peristiwa yang informatif. Tandelilin (2017) mendefinisikan event study sebagai penelitian untuk mengamati dampak rilis informasi terhadap harga saham yang berkaitan dengan kecepatan informasi mempengaruhi perubahan harga saham. Adapun alasan dilakukannya studi peristiwa adalah (Hartono, 2018) :

1. Menganalisi dampak peristiwa tersebut terhadap nilai perusahaan

https://doi.org/10.26593/jab.v17i2.5269.206-215 
2. Survei peristiwa digunakan untuk mengukur dampak langsung suatu peristiwa terhadap harga saham perusahaan pada saat peristiwa itu terjadi.

3. Pengumpulan data mudah dilakukan karena hanya menggunakan tanggal peristiwa dan harga saham perusahaan yang diteliti serta indeks pasar untuk mengetahui return pasar.

\section{Hubungan antara Variabel Abnormal Return dengan Peristiwa Penetapan UU Cipta Kerja}

Berinvestasi di pasar modal sangat diminati oleh masyarakat karena menjanjikan keuntungan yang tinggi meskipun memiliki risiko yang tinggi. Banyak sumber yang mengatakan bahwa saham (ekuitas) sangat diminati, meskipun sifatnya yang sangat sensitif terhadap peristiwa baik internal maupun eksternal. Peristiwa eksternal tidak dapat dikendalikan oleh perusahaan, seperti saat DPR RI menyepakati penetapan UU Cipta Kerja pada tanggal 5 Oktober 2020. Menurut Hadifz \& Isbanah (2020), abnormal return merupakan indikator reaksi pasar terhadap isi informasi dari pengumuman atau peristiwa. Peristiwa dapat dikatakan informatif apabila peristiwa tersebut mampu memengaruhi pasar modal. Penelitian yang dilakukan oleh Indriani \& Mariani (2021) menunjukkan bahwa average abnormal return pada periode sebelum dan sesudah peristiwa penetapan UU Cipta Kerja berbeda secara signifikan. Pengesahan undangundang ini menunjukkan upaya pemerintah untuk memberikan kepastian hukum terhadap iklim investasi Indonesia, khususnya sektor riil seperti manufaktur. Hal ini tentu saja mempengaruhi lingkungan investasi di pasar modal. Berdasarkan penjelasan tersebut, peneliti membuat hipotesis pertama sebagai berikut:

H1 : Ada perbedaan rata-rata abnormal return sebelum dan sesudah disahkan UU Cipta Kerja pada perusahaan manufaktur yang terdaftar dalam indeks LQ45

\section{Hubungan antara Variabel Trading Volume Activity dengan Peristiwa Penetapan UU Cipta Kerja}

Trading Volume Activity adalah aktivitas transaksi perdagangan di bursa saham dan merupakan cerminan dari keputusan investor dalam melakukan investasi, dimana semakin besar volume perdagangan berarti semakin informatif berita yang diterima investor, sehingga dapat digunakan untuk mengamati dampak peristiwa terhadap perdagangan saham (Hafidz \& Isbanah, 2020). Untuk mengetahui apakah ada reaksi pasar modal terhadap informasi dari suatu pengumuman, Aditha \& Adiputra (2020) menyatakan bahwa kehadiran sinyal berita yang terkandung dalam peristiwa tersebut dapat memicu reaksi pasar yang dapat dilihat dari volume perdagangan saham. Dengan begitu, volume perdagangan saham dapat meningkat atau menurun tergantung pada informasi yang terkandung di dalam pengumuman atau peristiwa tersebut. Hasil penelitian yang dilakukan oleh Islami \& Sarwoko (2012) menyatakan bahwa ditemukan perbedaan rata-rata trading volume activity (TVA) pada periode t-5 sampai dengan periode $t+5$ sejak diumumkannya kemunduran Sri Mulyani sebagai Menteri Keuangan Indonesia. Penurunan nilai TVA setelah peristiwa tersebut menunjukan bahwa peristiwa mundurnya Sri Mulyani sebagai Menteri Keuangan Indonesia menjadi sumber informasi bagi para investor untuk membuat keputusan perdagangan di pasar modal. Berdasarkan uraian tersebut, maka peneliti merumuskan hipotesis kedua sebagai berikut

$\mathrm{H} 2$ : Ada perbedaan rata-rata trading volume activity sebelum dan sesudah disahkan UU Cipta Kerja pada perusahaan manufaktur yang terdaftar dalam indeks LQ45

\section{METODOLOGI}

Penelitian ini berjenis studi peristiwa (event study) adapun peristiwa yang diuji adalah penetapan UU Cipta Kerja yang jatuh pada tanggal 5 Oktober 2020. Pengamatan dilakukan selama 21 hari yaitu 10 hari sebelum peristiwa, 10 hari sesudah peristiwa. Penggunaan periode pengamatan mengacu pada penelitian yang dilakukan oleh Husnan, Hanafi \& Wibowo (1996) yang menggunakan periode pengamatan atas variabel kegiatan perdagangan dan variabilitas tingkat keuntungan pada periode 10 hari sebelum dan 10 sesudah pengumuman. 
Populasi yang digunakan dalam penelitian ini adalah seluruh perusahaan yang terdaftar dalam Indeks LQ45 pada Agustus 2020 hingga Januari 2021. Indeks LQ45 dipilih karena ke-45 perusahaan yang tergabung di dalamnya mewakili berbagai bidang usaha, memiliki tingkat likuiditas yang tinggi, memiliki kapitalisasi pasar yang besar dengan fundamental perusahaan yang baik, serta tercatat di Bursa Efek Indonesia. Penentuan sampel dilakukan dengan metode purposive sampling. Adapun kriteria sample dalam penelitian ini adalah sebagai berikut

1. Perusahaan manufaktur yang termasuk ke dalam Indeks LQ45 pada periode Agustus 2020 - Januari 2021

2. Perusahaan melakukan transaksi dan memiliki harga penutupan saham (closing price)

3. Tidak mengalami delisting dan suspend selama periode penelitian

4. Tidak melakukan aksi korporasi (stock split, buyback saham, saham bonus, dan right issue) selama periode penelitian

Berdasarkan kriteria tersebut, diperoleh 14 perusahaan manufaktur yang dijadikan sampel penelitian. Data sekunder yang digunakan dalam penelitian ini terdiri dari data harga saham harian, volume perdagangan saham, dan jumlah saham yang beredar dari sampel terpilih serta Indeks Harga Saham Gabungan selama periode penelitian. Data diperoleh dari situs Dunia Investasi dan Bursa Efek Indonesia.

Teknik analisis data menggunakan uji sampel berpasangan (paired samples t-test) untuk menguji perbedaan rata-rata abnormal return dan trading volume activity sebelum dan sesudah penetapan UU Cipta Kerja.

\section{Operasionalisasi Variabel}

Operasionalisasi variabel digunakan untuk memudahkan dalam menjelaskan pengertian dan menghindari perbedaan-perbedaan persepsi dalam memahami penelitian ini. Penelitian ini menggunakan dua variabel yaitu abnormal return dan trading volume activity di sekitar tanggal penetapan UU Cipta Kerja.
Tabel 1. Operasionalisasi Variabel

\begin{tabular}{|c|c|c|}
\hline Variabel & Konsep Variabel & Indikator \\
\hline $\begin{array}{l}\text { Abnormal } \\
\text { return }\end{array}$ & $\begin{array}{l}\text { Kelebihan antara } \\
\text { imbal hasil yang } \\
\text { sesungguhnya } \\
\text { terjadi terhadap } \\
\text { imbal hasil } \\
\text { ekspektasian } \\
\text { (Hartono, 2018) }\end{array}$ & $\mathrm{RTN}_{\mathrm{i}, \mathrm{t}}=\mathrm{R}_{\mathrm{i}, \mathrm{t}}-\mathrm{E}\left[\mathrm{R}_{\mathrm{i}, \mathrm{t}}\right]$ \\
\hline $\begin{array}{l}\text { Trading } \\
\text { Volume } \\
\text { Activity }\end{array}$ & $\begin{array}{l}\text { Rasio antara } \\
\text { jumlah lembar } \\
\text { saham yang } \\
\text { diperdagangkan } \\
\text { pada waktu } \\
\text { tertentu terhadap } \\
\text { jumlah saham } \\
\text { yang beredar pada } \\
\text { waktu tertentu } \\
\text { (Utami A. T., } \\
\text { 2017) }\end{array}$ & TVA $=\frac{\begin{array}{c}\text { Vol Saham yg } \\
\text { diperdagangkan } \\
\text { pada waktu } \mathrm{t}\end{array}}{\begin{array}{c}\text { Vol saham yg } \\
\text { beredar pada } \\
\text { waktu } \mathrm{t}\end{array}}$ \\
\hline
\end{tabular}

\section{HASIL PENELITIAN DAN PEMBAHASAN}

Penelitian ini bertujuan untuk menguji respon pasar terhadap suatu peristiwa yang mengandung informasi. Peristiwa yang dimaksud adalah penetapan UU Cipta Kerja yang terjadi pada tanggal 5 Oktober 2020. Peristiwa ini bukan peristiwa konvensional yang sering terjadi melainkan termasuk peristiwa lingkungan makro yang tidak terduga sehingga ada kemungkinan investor belum memahami kandungan informasi atas peristiwa ini.

Pengujian hipotesis mengenai respon pasar terhadap kandungan informasi atas peristiwa penetapan UU Cipta Kerja pada 14 saham perusahaan sektor manufaktur dilakukan dengan cara menghitung apakah terdapat perbedaan abnormal return dan trading volume activity di sekitar tanggal pengumuman peristiwa. Periode pengamatan selama 21 hari dilakukan 10 hari sebelum dan 10 hari sesudah tanggal penetapan UU Cipta Kerja. Pengujian hipotesis pada penelitian ini menggunakan uji paired samples t test dimana data berdistribusi normal menjadi syarat yang harus terpenuhi dalam metode pengujian ini.

\section{Uji Normalitas}

Uji Normalitas digunakan untuk menguji normalitas data harga saham dan volume perdagangan saham pada periode pengamatan. Penelitian ini menguji perbedaan rata-rata abnormal return dan trading volume activity sebelum dan sesudah penetapan UU Cipta Kerja 
yang hanya mensyaratkan data berdistribusi normal. Uji normalitas yang digunakan adalah uji Kolmogorov Smirnov. Pengambilan keputusan dalam metode ini didasarkan pada nilai Monte Carlo Sig. (2-tailed). Data dinyatakan berdistribusi normal jika Monte Carlo Sig. (2-tailed) bernilai lebih besar dari 0,05. Sebaliknya jika nilai Monte Carlo Sig. (2-tailed) bernilai kurang dari 0,05 maka data tidak terdistribusi normal. Berikut ini adalah hasil uji normalitas untuk kedua variabel.

\begin{tabular}{|c|c|c|c|}
\hline Variabel & Periode & $\begin{array}{c}\text { Monte } \\
\text { Carlo Sig. } \\
\text { (2-tailed) }\end{array}$ & Keterangan \\
\hline \multirow[t]{2}{*}{ AAR } & $t-10$ & 0,617 & $\begin{array}{c}\text { Berdistribusi } \\
\text { normal }\end{array}$ \\
\hline & $t+10$ & 0,719 & $\begin{array}{c}\text { Berdistribusi } \\
\text { normal }\end{array}$ \\
\hline \multirow[t]{2}{*}{ TVA } & $t-10$ & 0,781 & $\begin{array}{c}\text { Berdistribusi } \\
\text { normal }\end{array}$ \\
\hline & $t+10$ & 0,637 & $\begin{array}{c}\text { Berdistribusi } \\
\text { normal }\end{array}$ \\
\hline
\end{tabular}

Jika dilihat pada tabel 1, nilai Monte Carlo Sig. (2-tailed) untuk variabel abnormal return (AAR) dan variabel trading volume activity (TVA) menunjukkan angka yang lebih besar dari 0,05. Dari hasil pengujian normalitas tersebut dapat disimpulkan bahwa data berdistribusi normal sehingga data layak untuk diuji menggunakan uji paired samples $t$-test.

\section{Uji Perbedaan Rata-rata Abnormal Return pada Peristiwa Penetapan UU Cipta Kerja}

Pengujian reaksi pasar yang pertama menggunakan indikator abnormal return. Hasil penelitian menunjukan bahwa rata-rata abnormal return pada periode pengamatan bergerak sangat dinamis seperti ditunjukkan pada gambar 1 berikut ini :

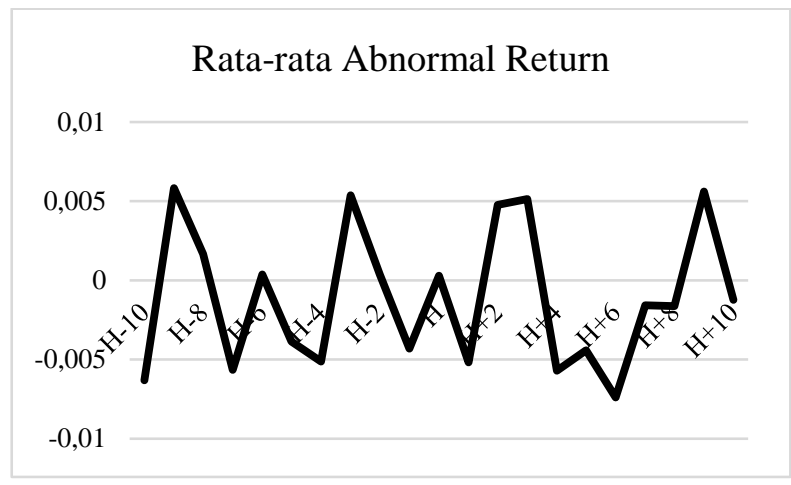

Gambar 1. Pergerakan Rata-Rata Abnormal Return

Gambar 1 menunjukkan bahwa pergerakan rata-rata abnormal return pada tanggal di sekitar penetapan UU Cipta Kerja sangat dinamis. Nilai abnormal return pada periode pengamatan selama 21 hari menghasilkan nilai tertinggi pada hari ke-9 sebelum pengumuman sedangkan nilai rata-rata abnormal return terendah terjadi pada hari ke-6 sesudah tanggal penetapan UU Cipta Kerja.

Pengujian hipotesis 1 mengenai perbedaan rata-rata abnormal return sebelum dan sesudah penetapan UU Cipta Kerja dilakukan dengan menggunakan alat analisis uji Paired Samples $t$ Test seperti yang disajikan pada tabel 2 . Pengambilan keputusan untuk menerima atau menolak hipotesis dengan melihat nilai signifikansi (nilai sig. $<0,05$ ).

Tabel 3. Hasil Uji Paired Samples $t$ Test Rata-rata Abnormal

\begin{tabular}{cccc}
\multicolumn{3}{c}{ Return } \\
\hline Variabel & Periode & Signifikansi & Keterangan \\
\hline AAR & $\mathrm{t}-10 ; \mathrm{t}+$ & 0,997 & Hipotesis \\
& 10 & & ditolak \\
\hline
\end{tabular}

Hasil uji hipotesis pertama menunjukan bahwa nilai signifikansi rata-rata abnormal return (AAR) besarnya 0,997 . Karena nilai signifikansi yang diperoleh menunjukkan 0,997 >0,05 maka hipotesis ditolak. Hal ini berarti tidak ada perbedaan rata-rata abnormal return antara sebelum dan sesudah penetapan UU Cipta Kerja. Hasil ini sejalan dengan kesimpulan penelitian yang dilakukan oleh Aditha \& Adiputra (2020) dan Hafidz \& Isbanah (2020) yang menyimpulkan bahwa tidak terdapat adanya perbedaan abnormal return saat sebelum dan sesudah peristiwa.

Adanya peristiwa dapat menyebabkan reaksi pasar berupa pergerakan harga saham yang berakibat terjadinya return bagi para investor. 
Abnormal return dihitung dengan cara mencari selisih nilai dari return aktual dengan return yang diharapkan di sepanjang periode pengamatan. Return aktual (return yang telah diperoleh) merupakan selisih harga saham periode $\mathrm{t}$ dengan $\mathrm{t}-$ 1 dibandingkan dengan harga saham t-1. Return yang diharapkan pada penelitian ini dihitung dengan menggunakan market model.

Hasil penelitian menunjukkan bahwa return aktual saham sektor manufaktur yang dijadikan sampel penelitian bergerak seiring dengan pergerakan return yang diharapkan. Return aktual yang dihitung secara harian menunjukkan nilai positif dan negatif bergerak sangat dinamis. Return aktual saham sebelum penetapan UU Cipta Kerja cenderung bernilai negatif sedangkan return aktual setelah penetapan UU Cipta Kerja menunjukan tren peningkatan yang positif

Return harapan yang dihitung menggunakan market model berdasarkan nilai IHSG menyimpulkan bahwa return harapan sebelum penetapan UU Cipta Kerja cenderung bernilai negatif sedangkan pada masa setelah penetapan UU Cipta Kerja return harapan cenderun bernilai positif.

Berdasarkan data pergerakan return aktual maupun return yang diharapkan, dapat dilihat bahwa pergerakan kedua return memiliki pola yang hampir sama sehingga hampir tidak terjadi abnormal return, baik pada masa sebelum maupun sesudah penetapan UU Cipta Kerja tersebut. Kondisi tidak terjadinya abnormal return ini menyebabkan hipotesis penelitan tidak terbukti.

Penetapan UU Cipta Kerja ini bertujuan untuk memberikan dukungan bagi perkembangan industrialisasi khususnya sektor manufaktur. UU Cipta Kerja yang telah disahkan pada tanggal 5 Oktober 2020 ini direspon secara positif oleh investor di pasar modal Indonesia yang tercermin dari penguatan nilai IHSG di atas $1 \%$ pada hari setelah penetapan UU tersebut dan penguatan ini berlanjut pada hari-hari perdagangan berikutnya.

Temuan dalam penelitian ini menunjukan bahwa penetapan UU Cipta Kerja mengandung informasi yang berpengaruh terhadap pergerakan return saham dan return pasar. Penetapan UU Cipta Kerja sebagai peristiwa lingkungan makro terkait perubahan regulasi memiliki kekuatan yang mampu memengaruhi kegiatan pasar modal. Penetapan UU Cipta Kerja ini diharapkan mampu mendorong sektor manufaktur untuk tumbuh dan berkembang yang pada akhirnya akan menarik minat pelaku pasar modal untuk berinvestasi di sektor manufaktur.

\section{Uji Perbedaan Rata-rata Trading Volume Activity pada Peristiwa Penetapan UU Cipta Kerja}

Reaksi pasar modal atas kandungan informasi suatu peristiwa dapat pula dilihat dengan menggunakan indikator trading volume activity. Grafik pergerakan trading volume activity nampak pada Gambar 2 berikut ini :

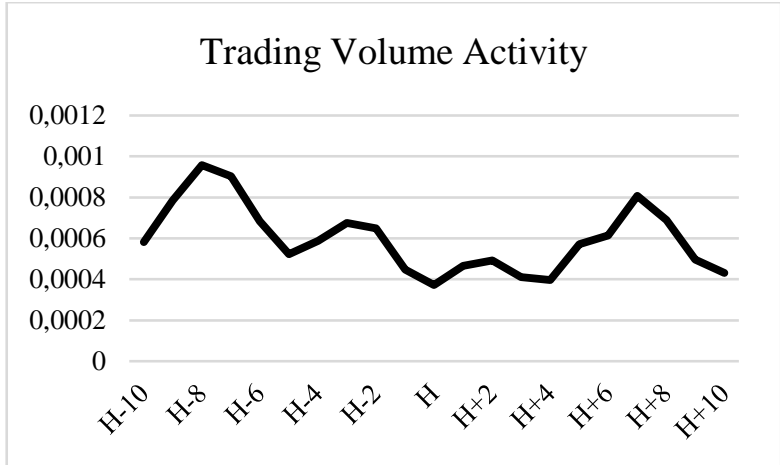

Gambar 2. Pergerakan Rata-Rata Trading Volume Activity

Gambar 2 menunjukkan pergerakan ratarata trading volume activity, yang mana pergerakan tersebut sangat dinamis. Hari ke-8 sebelum penetapan UU Cipta kerja menjadi hari dengan rata-rata trading volume activity tertinggi sedangkan nilai terendah terjadi pada hari ke-4 sesudah penetapan UU Cipta Kerja.

Pengujian hipotesis kedua mengenai aktivitas kegiatan perdagangan dilakukan dengan cara mengamati rata-rata Trading Volume Acticity (TVA) dalam periode 10 hari sebelum dan 10 hari sesudah penetapan UU Cipta Kerja. Tabel 2 adalah hasil uji perbedaan untuk Trading Volume Activity (TVA) yang menunjukan nilai signifikansi sebesar 0,004 . Nilai ini mengandung arti bahwa aktivitas volume perdagangan menunjukan perbedaan yang signifikan sebelum dan sesudah adanya penetapan UU Cipta Kerja. 
Tabel 4. Hasil Uji Paired Samples $t$ Test Rata-rata Trading Volume Activity

\begin{tabular}{lccc}
\hline Variabel & Periode & Signifikansi & Keterangan \\
\hline TVA & $\mathrm{t}-10 ; \mathrm{t}+$ & 0,004 & $\begin{array}{c}\text { Hipotesis } \\
\text { diterima }\end{array}$ \\
& 10 & & \\
\hline
\end{tabular}

Aktivitas perdagangan setelah penetapan UU Cipta Kerja lebih tinggi dibandingkan dengan sebelumnya. Hal ini menunjukkan bahwa investor merespon secara positif informasi yang masuk ke pasar yang tercermin dari adanya peningkatan aktivitas perdagangan di pasar modal. Aktivitas perdagangan sektor manufaktur sebelum penetapan UU Cipta Kerja cenderung landai dan mulai meningkat setelah tanggal penetapan UU Cipta Kerja tersebut. Peningkatan jumlah aktivitas perdagangan setelah penetapan UU Cipta Kerja menunjukkan bahwa investor optimis akan tumbuhnya sektor industri manufaktur yang dapat memperbaiki kondisi perekonomian Indonesia serta menciptakan lapangan kerja yang lebih luas.

Hal ini menjadi bukti nyata peran penting sektor industri manufaktur sebagai motor penggerak utama perekonomian nasional. Hal ini juga tercermin dari sumbangsihnya pada struktur PDB nasional pada triwulan II tahun 2020 dengan mencapai 19,87 persen.

Hal ini juga sejalan dengan kondisi pasar modal Indonesia seperti yang dikemukakan oleh Utamai (2020) dimana penetapan dan penerapan UU Cipta Kerja dinilai memberikan sentimen positif bagi pasar modal Indonesia. Reaksi pasar modal ini mengandung arti bahwa pasar menerima informasi terkait dampak positif atas penetapan UU Cipta Kerja ini, seperti dukungan sektor tenaga kerja, kemudahan untuk mendapat bahan baku bagi industri manufaktur, serta jaminan peningkatan produktivitas industri khususnya manufaktur.

Penelitian yang dilakukan oleh Islami dan Sarwoko (2012) dengan subyek penelitian serupa yaitu perusahaan yang masuk dalam indeks LQ45, menyimpulkan bahwa perusahaan dengan nilai kapitalisasi pasar yang besar sangat peka terhadap sebuah informasi.

\section{KESIMPULAN}

Hasil penelitian ini menunjukan bahwa tidak terdapat perbedaan rata-rata abnormal return pada saham perusahaan sektor manufaktur yang terindeks LQ45 sebelum dan sesudah penetapan UU Cipta Kerja. Hal ini disebabkan karena peristiwa penetapan UU Cipta Kerja tidak dapat segera direspon oleh pasar karena dampak dari UU Cipta Kerja ini akan baru bisa dirasakan secara jangka panjang. Investor pun tidak tergesa-gesa bereaksi terhadap informasi penetapan UU Cipta Kerja tersebut sehingga tidak menimbulkan abnormal return. Meskipun demikian reaksi positif atas informasi tersebut ditunjukan dengan adanya peningkatan volume perdagangan setelah hari penetapan UU Cipta Kerja. Volume perdagangan saham sektor manufaktur mengalami peningkatan setelah hari penetapan UU Cipta Kerja, sehingga terjadi perbedaan rata-rata trading volume activity walaupun belum mampu meningkatkan harga saham secara signifikan.

Peristiwa makro seperti penetapan UU Cipta Kerja ini dapat memengaruhi aktivitas pasar modal. Investor dapat menggunakan informasi ini sebagai sinyal positif akan berkembangnya sektor manufaktur di masa mendatang.

Penelitian ini menggunakan rata-rata abnormal return untuk mengamati reaksi pasar atas kandungan informasi dalam sebuah peristiwa. Penelitian selanjutnya dapat menambahkan variabel akumulasi abnormal return untuk melihat perkembangan abnormal return selama periode pengamatan.

\section{DAFTAR PUSTAKA}

Aditha, K. K., \& Adiputra, I. M. (2020). Analisis Perbedaan Abnormal Return, Trading Volume Activity dan Security Return Variability pada Perusahaan LQ45 Pra dan Pasca Pengumuman Kabinet Indonesia Maju Periode 2019-2024. JIMAT (Jurnal Ilmiah Mahasiswa Akuntansi), 11(2), 299309.

doi:http://dx.doi.org/10.23887/jimat.v11i2 .24958

Astuti, F., \& Prayoga, A. S. (2020). Market Reaction Analysis of Annual Report Award Announcement : An Event Study using Abnorma Return, Trading Volume Activity and Stock Prices. EkBis: Jurnal Ekonomi dan Bisnis, 4(1), 340-352. 
doi:https://doi.org/10.14421/EkBis.2020.4 .1 .1186

CNN Indonesia. (2020, Oktober). Retrieved from https://www.cnnindonesia.com/: https://www.cnnindonesia.com/ekonomi/ 20201006135421-532-554944/5-dampakomnibus-law-ciptaker-bagi-pekerja-diindonesia

Hafidz, M. F., \& Isbanah, Y. (2020). Analisis Komparatif Abnormal Return dan Trading Volume Activity berdasarkan Political Event (Event Study Pada Pengesahan RUU KPK 2019). Jurnal Ilmu Manajemen, $\quad 8(3), \quad 829-838$. doi:https://doi.org/10.26740/jim.v8n3.p82 9-838

Hartono, J. (2018). Menguji Reaksi Pasar Modal Akibat Suatu Peristiwa. Yogyakarta: BPFE.

Hartono, J. (2019). Teori Portofolio dan Analisis Investasi. Yogyakarta: BPFE.

Husnan, S., Hanafi, M. M., \& Wibowo, A. (1996). Dampak Pengumuman Laporan Keuangan Terhadap Kegiatan Perdagangan Saham dan Variabilitas TIngkat Keuntungan. Kelola, 110-125.

Imelda, Siregar, H., \& Anggraeni, L. (2014). Abnormal Returns and Trading Volume in The Indomesia Stock Market in Relation to the Presidential Elections in 2004, 2009 and 2014. International Journal of Administrative Science \& Organization, 21(2), 65-76.

Indriani, R., \& Mariana, M. (2021). Reaksi Pasar Modal Indonesia terhadap Peristiwa Pengesahan UU Cipta Kerja 2020 ( Studi Kasus Perusahaan yang Terdaftar Pada LQ45). Jurnal Bina Akuntansi, 8(2), 168188.

doi:https://doi.org/10.52859/jba.v8i2.174

Islami, L. N., \& Sarwoko, E. (2012). Reaksi Pasar Modal Indonesia Terhadap Pergantian Menteri Keuangan (Event Study Saham yang Terdaftar di BEI). Modernisasi, 8(1), 44-67. Retrieved from https://ejournal.unikama.ac.id/index.php/J EKO/article/view/206
Kementerian Investasi. (2020, September). Retrieved from https://www.investindonesia.go.id/: https://www.investindonesia.go.id/id/artik el-investasi/detail/omnibus-law-danperannya-dalam-menyuburkan-investasiindonesia

Kementerian Perindustrian Republik Indonesia. (2020, Oktober). Retrieved from https://kemenperin.go.id/: (https://kemenperin.go.id/artikel/22065/M enperin-Optimistis-UU-Cipta-KerjaWujudkan-Reindustrialisasi

Mahmood, S., Irfan, M., Iqbal, S., Kamran, M., \& Ijaz, A. (2014). Impact of Political Events on Stock Market: Evidence from Pakistan. Journal of Asian Business Strategy, 4(12), 141-152. Retrieved from http://aessweb.com/journaldetail.php?id=5006

Otoritas Jasa Keuangan. (2016). Retrieved from https://www.ojk.go.id/: https://www.ojk.go.id/sustainablefinance/id/tentang/Pages/PasarModal.aspx

Prihastini, N. M., \& Suprasto, B. (2017). Reaksi Pasar Modal Terhadap Undang Undang Republik Indonesia No. 11 Tahun 2016 tentang Pengampunan Pajak. e-jurnal Akuntansi , 21(2), 1026-1051. doi:https://doi.org/10.24843/EJA.2017.v2 1.i02.p06

Sugianto, D. (2020, Oktober). Retrieved from https://finance.detik.com/: https://finance.detik.com/bursa-danvalas/d-5202870/angin-segar-omnibuslaw-buat-ihsg-dan-rupiah

Tandelilin, E. (2017). Pasar Modal Manajemen Portofolio dan Investasi. Yogyakarta: Kanisius.

Undang-Undang Cipta Kerja No. 11 Tahun 2020 tentang Cipta Kerja, 2 November 2020 (Lembaran Negara Republik Indonesia Tahun 2020 Nomor 245 Tambahan Lembaran Negara Republik Indonesia Nomor 6573).

Utami, A. T. (2017). Analisis Trading Volume Activity dan Abnormal Return Sebelum 
dan Sesudah Melakukan Pemecahan Saham Pada Perusahaan Yang Terdaftar Di Bursa Efek Indonesia. Jurnal Ekobis, 18(2), 164-173. doi:http://dx.doi.org/10.30659/ekobis.18.2 .164-173

Utami, D. N. (2020, Oktober). Retrieved from https://market.bisnis.com:

https://market.bisnis.com/read/20201015/ 7/1305681/omnibus-law-bawa-efekpositif-ke-pasar-modal-aei-berikandukungan 